Fecha de recepción: febrero 2019 Fecha de aceptación: marzo 2019 Versión final: mayo 2019

\section{Memoria, olvido y perdón en la Gran Guerra. El universo femenino en Frantz (Ozon, 2017)}

Mercedes Pombo ${ }^{*}$ y Zulema Marzorati ${ }^{\star *}$

Resumen: El presente artículo propone analizar el film Frantz centrándose en los cambios de la mujer a lo largo de la historia. El relato, contextualizado en Alemania y Francia a fin de la Primer Guerra Mundial, muestra las consecuencias de la guerra dadas por la muerte de hombres jóvenes, tragedias familiares y desolación, lo cual destruyó la confianza que los europeos habían tenido hasta entonces en su propia civilización. Con un discurso antibelicista el texto fílmico rememora esa etapa de desilusión y desesperanza a través de sus tres personajes centrales: Frantz, alemán muerto en las trincheras, Anna, su novia y Adrien, francés que se presenta en Alemania como un amigo de Frantz de antes de la guerra.

Como la historia no puede desprenderse de los discursos ni de las imágenes que la representan el objetivo de nuestro trabajo es abordar la construcción de la memoria (y los riesgos del olvido) sobre las consecuencias de la Gran Guerra a la vez que indaga sobre la mirada femenina en este contexto. Según de Beauvoir (1987) es posible inferir que las características consideradas propias de las mujeres no resultan de lo natural sino como un complejo proceso social. Las mujeres adquieren características consideradas como femeninas mediante un procedimiento que las determina como la contracara de lo masculino. En el film podemos analizar claramente estos roles y cómo en el transcurso de la historia estos límites van desdibujándose para dar lugar a nuevos paradigmas. Ozon se centra en la figura femenina, Anna, quien de simple espectadora que espera y sufre la pérdida de su amado, se transforma a lo largo del relato en una mujer activa. Es a través de su mirada que el realizador reflexiona sobre lo absurdo de la guerra, el perdón y la reconciliación, el arte como escape al horror y en particular la búsqueda de la libertad de la mujer en una sociedad patriarcal.

Palabras clave: Gran Guerra - memoria - olvido - género - imágenes

[Resúmenes en inglés y portugués en las páginas 109 - 110]

${ }^{(*)}$ Licenciada y Profesora en Enseñanza Media y Superior en Artes Plásticas (UBA). Docente, investigadora y fotógrafa. Actualmente cursa el Magister de Comunicación y Creación Cultural (CAECE - Fundación Walter Benjamín). Ejerce la docencia en la Universidad de Palermo y el instituto ISEC y se desempeña como coordinadora del Programa de Estímulo a la Investigación DC, Universidad de Palermo. Coordinadora junto con Zulema Marzorati de los Cuadernos del Centro de Estudios de Diseño y Comunicación. Cine e Historia. Representaciones fílmicas en un mundo globalizado. Facultad de Diseño y Comunicación. Universidad de Palermo Buenos Aires, Argentina. Cuaderno Nº77, 2020. 
ISSN 1668-0227; y Cuaderno del Centro de Estudios de Diseño y Comunicación Cine e Historia. Pluralidad de voces y miradas sobre el autoritarismo y el totalitarismo Facultad de Diseño y Comunicación $N^{\circ}$ 68. Universidad de Palermo, Buenos Aires, Argentina. ISNN 1668-0227. Año XVIII. ISSN 1668-0227 - 2018

${ }^{(*)}$ Doctora en Ciencias Sociales (UBA). Magister en Ciencias Sociales con orientación en Historia (Flacso). Docente e investigadora (UBA). Actualmente investiga las representaciones de la ciencia en documentales argentinos, habiendo publicado diversos artículos sobre esta temática. Integra el -Proyecto UBACYT 2018- 2020/ 20020170100593BA Grupos consolidados. Tema: Co-producción de conocimiento: nuevos formatos asociativos y materialidad de la creatividad científica. Facultad de Filosofía y Letras. Directora: Dra. Cecilia Hidalgo. 2001-2017- Coordinadora con Tzvi Tal de las Jornadas Interescuelas. Departamento de Historia. UBA 2012- Plantear utopías. La conformación del campo científico-tecnológico nuclear en Argentina 1950-1955, Buenos Aires: Ciccus. Coordinadora junto con Mercedes Pombo de los Cuadernos del Centro de Estudios de Diseño y Comunicación. Cine e Historia. Representaciones fílmicas en un mundo globalizado. Facultad de Diseño y Comunicación. Universidad de Palermo Buenos Aires, Argentina. Cuaderno Nº77 - 2020. ISSN 1668-0227; y Cuaderno del Centro de Estudios de Diseño y Comunicación Cine e Historia. Pluralidad de voces y miradas sobre el autoritarismo y el totalitarismo Facultad de Diseño y Comunicación $N^{\circ}$ 68. Universidad de Palermo, Buenos Aires, Argentina. ISNN 1668-0227. ISSN 1668-0227 - 2018

- Este trabajo integra el UBACYT No 20020170100593BA 2018-2021del proyecto "Coproducción de conocimiento: nuevos formatos asociativos y materialidad de la creatividad científica" dirigido por la Dra. Cecilia Hidalgo

La mayoría de las mujeres no son ni prostitutas ni cortesanas; ni se pasan las tardes de verano acariciando perritos falderos sobre terciopelos polvorientos. Pero ¿qué hacen entonces? (Woolf, 2008, p64)

\section{Introducción}

Con la Primera Guerra Mundial' ${ }^{1}$ (1914-1918) se derrumbó el mundo decimonónico, que se había construido a partir de la Revolución Francesa, basado en el credo liberal y la fe en el progreso indefinido ${ }^{2}$. En su mayor parte la contienda fue una guerra civil europea entre países industrializados o que iba camino de serlo, una guerra total que movilizó los recursos de todas las naciones y que careció de una base ideológica, como la tuvo la Segunda Guerra Mundial (Briggs y Clavin, 1997). 
Los bloques enfrentados fueron la Triple Entente integrada por Gran Bretaña, Francia y Rusia, a las que se sumarían Estados Unidos y Japón y, la Triple Alianza conformada por los imperios alemán, austro húngaro y turco. Pese a que se especulaba que sería corta, finaliza en 1918 con el triunfo de los aliados y las terribles consecuencias de 16 millones de muertos y otros 20 millones de heridos y mutilados.

La prolongación de la guerra modificaría la conciencia moral europea y el clima intelectual y cultural de la posguerra cristalizó en una cultura del pesimismo (Fusi Aizpurúa, 1991, p. 328). Son muchos los autores que en la década del '20 se refieren a esta crisis de Europa, hasta ese momento centro hegemónico del mundo, como Arnold Toynbee con El declinar de Europa (1920); Oswald Spengler y La decadencia de Occidente (1918); Thomas Mann con La montaña mágica (1924); y Erich María Remarque Sin novedad en el frente y Ernest Hemingway Adiós a las armas, ambos libros publicados en 1929.

Como la historia no puede desprenderse de los discursos ni de las imágenes que la representan ${ }^{3}$ el objetivo de nuestro trabajo es abordar la construcción de la memoria (y los riesgos del olvido) sobre las consecuencias de la Gran Guerra en el film Frantz en el que Ozon ${ }^{4}$ vuelve sobre este tema una centuria después desde la perspectiva de la figura femenina.

Con un discurso antibelicista, el texto fílmico rememora esa etapa de desilusión y desesperanza a través de tres personajes centrales: Frantz (Anton Von Lucke), alemán muerto en las trincheras; Ana (Paula Beer), su novia, y Adrien (Pierre Ninney), exsoldado francés que se presenta en Alemania como un misterioso amigo de Frantz de antes de la guerra, dejando flores en su tumba. Es recibido con afecto por los padres de Frantz, que ignoran lo que Anna sabe: que Adrien lo mató en las trincheras. Frantz es el personaje ausente, pero siempre presente, alrededor del cual girarán todos los demás protagonistas en un melodrama construido a partir del duelo, la reconciliación y el perdón.

La película se basa en una versión libre de Remordimiento (Broken Lullaby ,1932) la única película que Ernst Lubitsch ${ }^{5}$ realizó en Hollywood, una rareza en la filmografía del director alemán conocido por sus comedias. El original, filmado antes del estallido de la segunda guerra en 1939, era una clara alusión a esa posibilidad de otra gran guerra, que luego se concretaría. También toma como eje central el rencor entre alemanes y franceses luego de la Primera Guerra Mundial, y de la misma manera Ozon insiste a través de Anna y Adrien en un espejo de contemporaneidad : odios y rencores entre ambos países. El realizador francés, basado en otro film dirigido por un alemán, busca reconciliar esas memorias enfrentadas a través de una representación simbólica como lo es Frantz, con la participación de actores de ambas nacionalidades.

Atravesado por aspectos que hacen al absurdo de la guerra, con su consiguiente muerte y desolación y al arte como escape al horror, Frantz constituye además una metáfora para abordar a través de Anna y su punto de vista, la búsqueda universal de la libertad y el logro de los derechos de las mujeres en una sociedad patriarcal. Y esta búsqueda, que se resignifica en la actualidad, es el objetivo que proponemos a través de los ojos de Anna. Un personaje que resulta central en la historia, ya que sin quererlo aglutina franceses y alema- 
nes. Es ella quien recorre ambos países, es a través de sus ojos que vemos las consecuencias materiales y psicológicas que prevalecen en ambas naciones. Pero también a través de sus acciones y palabras podemos reflexionar acerca del rol de la mujer en esa época y pensar cómo fue encontrando su camino a lo largo de la historia.

Resulta muy importante hacer referencia a los estudios de género y la distinción de dos conceptos: sexo y género. Esta distinción puede rastrearse a partir del trabajo planteado por $\mathrm{Si}$ mone de Beauvoir quien en 1949 sentaría las bases del género como una construcción social: "No se nace mujer, se llega a serlo. Ningún destino biológico, psíquico o económico define la figura que reviste en el seno de la sociedad la hembra humana" (1987, pg 87). A través de estas palabras, es posible inferir que las características consideradas propias de las mujeres no resultan de lo natural sino como un complejo proceso social. Las mujeres adquieren características consideradas como femeninas mediante un procedimiento que las determina como la contracara de lo masculino. Esta misma autora plantea que el concepto de género es considerado como un conjunto de ideas, creencias y representaciones sociales construidas en cada cultura. En la película analizada esta construcción queda en evidencia cunado nos centramos en las actitudes de Anna, la protagonista femenina.

Ella atraviesa varios momentos, algunos basados en imposiciones sociales tales como quedarse en una constante actitud pasiva frente a la muerte de su prometido, dejar que su vida transcurra en casa de sus suegros, envolverse en un silencio basado en sus propias inseguridades como mujer. Pero hay otros momentos en que vemos una nueva Anna, muy contraria a lo impuesto por la sociedad y que va dando forma a una mujer protagonista de su vida, que encuentra su propio camino, lo cual rompe con las reglas establecidas para su género. Otro punto importante en el film es indagar acerca de lo que significa que la narración se encuentre atravesada por la mirada de una mujer, sobre todo teniendo en cuenta el lugar que históricamente ocupó el sexo femenino en las cuestiones sociales y políticas. De Beauvoir (1987) afirma que dentro de la sociedad siempre el hombre es el sujeto y la mujer se presenta como lo otro en relación a este sujeto, es la contracara que está determinada por el hombre. Lo femenino es planteado como lo extraño, lo ajeno, frente a un mundo definido por lo masculino. Es la mirada del hombre la que determina los modos de vida y de pensamiento, donde se encuentra la verdad y las respuestas. No resulta un detalle menor encontrarnos frente a un film que, pese al claro protagonismo de la dupla Frantz - Adrien, orbita en función del universo que se despliega tras la mirada de Anna. Y a través de ella podemos reconocer el "otro" punto de vista acerca de temas como la guerra, la paz, el perdón y los rencores. La Gran Guerra significó un cambio profundo en el rol de las mujeres a través de un protagonismo esencial en el hogar, el trabajo y también, en el frente. Y pese a que solían ser invisibles en la historia europea en tiempos de paz, obtuvieron un importante progreso en el terreno socio-político y económico durante la guerra, y sobre todo, al finalizar la misma (Brigss y Clavin ,1997).

Millones de hombres fueron al frente, y en la retaguardia, en ausencia del marido, las mujeres tuvieron que asumir el papel de jefe de hogar. Sin duda, la movilización laboral femenina contribuyó a modificar su lugar en la sociedad. Antes relegadas a las tareas domésticas, accedieron a puestos tradicionales masculinos, ya sea en los campos, explotando solas las granjas o, como obreras asalariadas, particularmente en la industria de armamen- 
tos como los obuses y cañones. Para reemplazar a los hombres movilizados, se tuvo que contratar cada vez más munitionettes, trabajadoras que fabricaban municiones.

La guerra les significó un período de relativa emancipación. En el caso de las mujeres de clase media y de la burguesía que ejercieron actividades como taquígrafas, maestras, secretarias, ello les permitió conseguir empleos estables y mejores niveles salariales, adquiriendo así una relativa autonomía. Un aporte importante, fue el realizado en toda Europa como enfermeras y ayudantes médicas, con el cuidado de heridos durante la guerra. Miles de ellas tuvieron un rol muy activo en el frente y en contacto directo con los aspectos más duros del enfrentamiento bélico.

Sin embargo, la guerra terminada, con la desmovilización y el regreso de los hombres del frente, numerosas mujeres perdieron su empleo ya que se suponía que debían volver a ocuparse de las tareas domésticas. "Pero la parte del botín más visible que les tocó después de la guerra fue el voto” (Briggs y Clavin, 1997, p. 225). En 1914 ya se habían superado los argumentos que las caracterizaba como irracionales y sin sentido común, y había comenzado a prepararse el terreno para extender el derecho al sufragio femenino.

El análisis del film se organiza a partir de los dos grandes momentos que atraviesa Anna, uno sobre su vida en Alemania y el otro cuando viaja a Francia. Su mirada es la que nos va acompañando en ese transcurrir por los diferentes espacios y escenarios que se muestran, tanto en el ámbito público como en el privado. Ambos lugares son mostrados por el director a modo de espejo, donde las circunstancias que rodean la posguerra, el nacionalismo y la pérdida de seres queridos es una situación que afecta a la vida cotidiana por igual, sea los vencedores o los vencidos.

\section{Contexto y estética en Frantz}

En la primera mitad del film vemos la vida de Anna en Alemania, en la ciudad de Quedlinburg, un pequeño pueblo de Baviera donde vivía su historia de amor con Frantz. Allí conocemos la relación con los padres de su prometido muerto que la han adoptado como una hija y el contexto en el que se encuentra la familia al momento de la llegada de Adrien. La segunda mitad del relato transcurre en Francia, adonde viaja Anna en busca de Adrien, allí muchos de las escenas que vimos en Alemania vuelven a ocurrir a modo especular y -siempre desde los ojos de Anna- experimentamos ambos espacios de posguerra.

El relato comienza en Alemania, donde vemos que Anna (Paula Beer) continúa viviendo con los padres de su prometido muerto en las trincheras. Ella visita diariamente la tumba vacía de Frantz, ya que su cuerpo quedó en los campos de batalla de Francia. Las cosas cambian con la llegada de Adrien Rivoire (Pierre Niney), primero rechazado por el padre de Frantz, el doctor Hans Hoffmeister (Ernst Stötzner): No puedo atenderlo, todo francés es para mí el asesino de mi hijo, pero luego es bien recibido en su casa cuando se presenta como amigo de Frantz en París y cuenta historias de la relación entre ambos.

El film transcurre en 1919, un año nodal para la historia de Alemania ya que se encuentra dentro de los perdedores de la guerra y los representantes de la reciente República firman el 28 de junio el Tratado de Versalles. En él, Alemania recibe las siguientes sanciones: debe 
renunciar a todos sus derechos y aspiraciones sobre sus posesiones de ultramar, a beneficio de las principales potencias aliadas; el ejército alemán no podrá exceder de cien mil hombres, incluyendo oficiales, quienes no podrán sobrepasar los cuatro mil; queda abolido el servicio militar; debe entregar todos los submarinos a los aliados y destruir todos los buques de guerra que estén en construcción; además de devolver los territorios de Alsacia y Lorena arrebatados después de la guerra franco-prusiana de 1871, y como reparación a los daños de guerra cometidos en territorio francés, cede a Francia la propiedad de las minas de hulla situadas en la cuenca del Sarre (que el plebiscito de 1935 devolvería a Alemania). Considerada responsable de todas las pérdidas y daños sufridos por los gobiernos aliados, deberá pagar reparaciones por un total de 132.000 millones de marcos oro (aproximadamente 33.000 de dólares).

En la ciudad alemana de Quedlinburg se vive el clima de humillación y rencor por la derrota. La tristeza por la muerte de tantos soldados se percibe en sus habitantes, la austeridad del pueblo remite a tiempos difíciles.

Por otro lado, en Francia la realidad es otra aunque -según lo representado por Ozonno tan diferente a Alemania. Las consecuencias de la posguerra son difíciles para ambos países. Con el Tratado de Versalles Francia recupera los territorios de Alsacia y Lorena y recibe posesiones en África y el Oriente Cercano, favoreciendo su posición hegemónica en Europa. La década que se inicia en el ' 20 será de prosperidad para el país, a diferencia de Alemania cuya situación monetaria será gravísima.

Debido a las enormes deudas de guerra contraídas con Estados Unidos y Gran Bretaña, se cuenta para devolverlas con las reparaciones de guerra alemanas, aunque éstas no proporcionarán las cantidades necesarias para hacerlo. Por ello, la seguridad para Francia parece residir en el estricto cumplimiento del Tratado de Versalles.

Lo más terrible de las consecuencias de la Gran Guerra fue el enorme costo humano. Casi ocho millones de hombres fueron movilizados y 1322.100 de ellos murió. Muchos otros (tres millones) fueron mutilados o debilitados por la experiencia. Fueron más de un millón los que recibieron pensiones por invalidez (Price, 1996). Esto produjo una fuerte regresión demográfica debido al declive de matrimonios y nacimientos, lo que sumado al éxodo rural, aceleraron la transformación de la estructura poblacional.

Esta realidad de dolor, duelo y muerte puede verse reflejado en toda la película, en ambos países y muchas de las elecciones estéticas del director hacen alusión a este contexto de posguerra, en especial el uso del blanco y negro en la mayoría de las escenas del film 6 . Esta elección surge también por la necesidad del director de hacer verosímil su puesta en escena, ya que según su visión el recurso del blanco y negro consigue una mayor veracidad al hacer eco de las referencias visuales y audiovisuales de la época, también monocromas ${ }^{7}$. Si bien el color no aparece con tanta frecuencia en el film, se hace presente en algunas escenas, pero su uso no tiene una lógica obvia ni unidireccional. No es solo por el retorno al pasado, ni tampoco cuando se recuerda o sucede algo bueno. Pero si puede ser agrupada en dos grandes situaciones que se dan en la película: por un lado cuando uno de los personajes recuerda o imagina vivencias con Frantz; y por otro lado cuando el film se acerca a la realidad interna más profunda de cada personaje.

En el primer caso el color surge como protagonista en las escenas basadas en la imaginación de Adrien o Anna: tales como Adrien paseando por el Louvre con Frantz, o ambos 
tocando el violín. Son momentos imaginados que tienen como protagonista la figura de Frantz y todo lo que ella representa..

En el segundo caso es cuando la realidad más profunda se manifiesta en la pantalla. La mayor parte de la película se muestra en colores monocromos porque esa es la realidad en la superficie: un gris por sobre otro gris. La vida de los padres, la vida de Anna, el dolor por la pérdida de Frantz, la culpa de Adrien. Pero cuando surge el color es porque nos está mostrando algo más, o un dolor profundo (la escena en que Adrien mata a Frantz) o una gran esperanza (Anna y Adrien disfrutando de la naturaleza y comenzando a enamorarse, o la escena final de ella en libertad). La verdadera vida es esa.

Por otro lado, dentro del relato es posible distinguir claramente el espacio público y las diferencias de lo que allí acontece. Por un lado en el espacio público es donde se manifiestan las relaciones sociales y el desánimo de los ciudadanos frente a ese contexto de posguerra. Allí podemos analizar el rol de la mujer en este contexto, cuáles son sus espacios de acción y silencio; cuales son los roles masculinos, qué puede sentir, decir y pensar Anna.

Por otro lado, frente a la gran historia de los Estados, las economías y las sociedades, se encuentra el ámbito privado, familiar . Así, en la casa de los padres de Frantz en Alemania y la casa de la madre de Adrien en Francia, es posible recuperar los sentimientos "puertas adentro" de los ciudadanos con respecto a la guerra y a los roles femeninos, en ambos casos. Para el desarrollo de este análisis proponemos tres líneas: lo público, lo privado y la conexión y unión de ambos espacios condensados en el Museo del Louvre, donde simbólicamente se conectan ambas esferas junto con el descubrimiento de la verdadera cara de Anna. Y también el espacio que alberga los cuadros de Manet, especialmente El suicidio, una obra que no es de las más conocidas del artista pero que Ozon elige como centro del relato y que de algún modo simboliza esta actitud de horror y muerte que se desprende de la Segunda Guerra Mundial.

\section{El espacio público}

Uno de los lugares más emblemáticos para analizar lo público dentro de Alemania y Francia es el espacio de la cervecería/bar, allí vemos resumida parte de los pensamientos y actitudes de cada nación.

En Alemania se trata de un grupo de hombres que se reúnen regularmente en una cervecería de la ciudad, donde advertimos la exaltación del sentimiento nacionalista y el odio hacia los franceses. El pretendiente de Anna, que no es tenido en cuenta por ella, deja en claro un deseo que será retomado por el partido Nacional Socialista de los Trabajadores Alemanes: que Alemania vuelva a ocupar un papel preponderante en el concierto de las naciones europeas. Y será Hitler, "el agitador de cervecería”, quien desde 1920 recorrerá esos locales de bebidas en Munich y con su discurso violento y revanchista contra las sanciones del Tratado de Versalles, llamará a la unidad nacional (Kershaw, 1999, p. 147). En la misma cervecería de Quedlinburg encontramos también representado en forma explícita el anti-belicismo cuando el padre de Frantz frente al mismo grupo de amigos que le reprochan que recibiera a Adrien en su casa, ofrece una mirada humanista en medio de la muerte y plantea la responsabilidad de los padres al enviar a la muerte a sus hijos en 
defensa de un sentimiento patriótico, incentivado e infundido por ellos. Aquí establece una similitud con los padres franceses: Mientras nosotros brindábamos con cerveza por la muerte de sus hijos, ellos lo hacían con vino, festejando la de los nuestros. A través de este discurso pacifista, el texto fílmico rememora la muerte de tantos jóvenes, pero no menciona la principal causa que condujo a la guerra: la apetencia imperialista de las potencias participantes. Anna experimenta en el bar de Francia vivencias parecidas a las que padece Adrien en Alemania. Ella percibe el mismo sentimiento nacionalista que Adrien vivió en Alemania y se siente extraña en ese lugar cuando ante la entrada de militares franceses, el público se va poniendo de pie y entona al unísono y con un fuerte sentimiento patriótico, la Marsellesa. Esta secuencia nos remite a las imágenes de otro film emblemático, Casablanca (EUA, Curtis, 1942) en el que en el bar de Richie se canta el himno de Francia ante la entrada de alemanes y colaboracionistas franceses.

La joven no puede integrarse en el canto y se aleja del bar. En su mirada está clara la perturbación que le significa el odio y el resentimiento entre franceses y alemanes, aunque la guerra haya terminado. Es relevante que sólo conozcamos su nombre de pila: Anna, mientras las dos familias son conocidas por sus apellidos: Rivoire y Hoffmeister, quizá como facciones que connotan el enfrentamiento entre los dos países. Anna pareciera no tener nacionalidad; quedó en el medio de ambas, desolada y desgarrada, habiendo perdido lo que más amaba.

Otro de los espacios que aparece con mucho protagonismo en ambos países es el cementerio: es aquí donde se concentra la mayor tristeza, donde se percibe una ausencia alrededor de la cual se moverán los personajes. En Alemania es allí donde Anna conoce a Adrien, y es en este espacio de muerte donde el joven confesará el asesinato de Frantz en la trinchera. La evocación de ese hecho nos lleva al absurdo que significa una guerra, donde se enfrentan jóvenes para matar o morir. La imagen de Frantz muerto, su posición y el hecho que Adrien encontrara una carta en su chaqueta, nos remite a la muerte anónima de otro soldado francés en la célebre secuencia de otro film antibélico: Sin novedad en el frente (EUA, Milestone, 1930), basada en la novela de Eric María Remarque, que también trata sobre el desengaño de la guerra y la defensa de la patria.

Para no entristecer más a sus padres adoptivos que ya se encariñaron con Adrien y lo consideran como un hijo suyo, Anna construye su propio relato diciéndoles que debe volver a Francia porque su madre está enferma. En la despedida a Adrien en la estación de ferrocarril la música extra-diegética de Beethoven nos recuerda que Todos somos hermanos... Anna no puede recuperarse de este adiós, intenta suicidarse pero algo la contiene y la hace tomar una decisión muy distinta: viajar a Francia, buscar a Adrien, elegir sus propios deseos.

En Francia también Anna llega hasta el cementerio, muy angustiada, porque en el listado de muertos figuraba el soldado Adrien Revoire. Pero ante la tumba de ese combatiente ya mayor, comprende que no es el joven que ella busca, sino probablemente su pariente. A diferencia de sus visitas al cementerio en Alemania, donde, vestida de negro, quedaba horas recordando a su amado muerto cerca de su tumba vacía, Anna se aleja rápidamente del lugar. En este caso toma una actitud activa, no se deja vencer por el miedo y la desesperación sino que decide averiguar quién es el muerto y dónde está Adrien. En la casa del tío de Adrien, su esposa le da la dirección dónde encontrarlo y le cuenta que este pariente 
se había suicidado, no pudiendo soportar los horrores presenciados y la muerte de sus soldados. Nuevamente aparece el tema del suicidio.

Por último, las calles, los alrededores, el tren en el que llega Adrien a Alemania y el tren en que viaja Anna a Francia, todos estos espacios son focos de atención acerca de los vínculos sociales que se presentan en ese contexto. La primera escena del film es el recorrido de Anna por las calles de su ciudad hasta llegar al cementerio, a través de su mirada vemos la gente, los ánimos y desánimos. También vemos a Anna y Adrien en las afueras de Quedlinburg, en un paisaje de río y montañas donde, lejos de los ecos de la guerra, se permiten ser libres, tomar sol, conversar sobre poesía, recordando versos del poeta Verlaine. Adrien se baña en el río, despojándose de su ropa y liberándose de los tristes acontecimientos que lo llevaron a Alemania. También en esos espacios públicos, específicamente en la calle es donde Adrien propone a Anna ir juntos al baile que se llevará a cabo al día siguiente. Allí bailan y ríen, siendo estas imágenes de alegría las que siempre deberían acompañar a los jóvenes, y no el odio y el dolor de las ausencias.

Cuando Anna camina por las calles de Francia, recibe los sentimientos y rencores que dejó la contienda. Lo mismo que a Adrien en Alemania, por su nacionalidad, es mirada con desconfianza por el guarda del tren que la lleva a París y por sus ocasionales compañeros de viaje. Quizá la diferencia pueda estar en que en la ciudad parisina hay mucha gente y Anna que habla muy bien el francés, se pierde en la multitud. Aunque Adrien habla alemán, su llegada a una pequeña ciudad como Quedlinburg, no pasa desapercibida para sus habitantes, que lo hostigan.

En su búsqueda, ella recorre los lugares que Adrien mencionó en sus relatos: el hotel donde se hospedaba Frantz al llegar a la ciudad, la Ópera de París, el Louvre, el hospital en el que lee el listado de muertos y desaparecidos en combate, hasta finalmente arribar a la enorme casa de las afueras de París donde reside el joven galo.

\section{El espacio privado}

Para Duby (1989) lo privado es “(...) un área particular y netamente delimitada, asignada a esa parte de la existencia que todos los idiomas denominan como privada, una zona de inmunidad ofrecida al repliegue, al retiro donde uno puede abandonar las armas y las defensas de las que le conviene hallarse provisto cuando se aventura al espacio público, donde uno se distiende (...) Es un lugar familiar. Doméstico.” (1989, p.10)

Para analizar los espacios privados nos enfocamos en el entorno familiar, en la historia de los individuos: sus miedos, angustias, alegrías y sueños, que quedan en evidencia en las escenas dentro de las casas, tanto de los padres de Frantz en Alemania como de la familia de Adrien en Francia.

La casa de Frantz, recrea la pequeña burguesía urbana, y donde, pese al resentimiento y la tristeza por la guerra y la pérdida de su hijo, es recibido por sus padres, interrumpiéndose la rutina y la apatía familiar ante los relatos que refieren a la amistad entre los dos jóvenes en el París anterior a la guerra. Pero, desde un comienzo a Adrien se lo ve visiblemente atormentado y preocupado, como si debiera cumplir con un cometido que no conocemos. 
Lo impulsa la culpa y mientras dice mentiras piadosas por no poder enfrentar la verdadera razón de su viaje, se va construyendo una relación afectiva con Anna y los padres de Frantz, que lo tratan como a un hijo más.

Siendo la muerte y la culpa uno de los ejes del film, el clima en la casa es de tristeza: las fotos en el álbum y en lo retratos muestran a un Frantz joven, en la plenitud de su vida; su interés y admiración por la cultura francesa; su amor por el violín, que Adrien comparte ya que integra la orquesta de París. Adrien, Frantz y Anna, que toca el piano, están unidos por la música y el amor al arte, es decir por la paz y no la guerra

Toda esta situación influye sobre Adrien, quien preso de remordimiento se siente mal y al caer desmayado asumiendo la misma posición del joven suicida en el cuadro de Manet. Toda una representación de que son los jóvenes las reales víctimas de la guerra.

Cuando Adrien regresa a Francia, con la excusa de su madre enferma, la casa familiar queda otra vez sumida en la tristeza y desesperanza. Son las cartas que Anna recibe del joven, las que la impulsan a dejar ese espacio privado, que la limita en su crecimiento y aventurarse al público, en París.

Las diferencias sociales entre Anna y Adrien se evidencian en la gran casa donde el joven vive en las afueras de París: hay una larga senda para acceder a ella, que sus moradores recorrerán en un carruaje y que Anna recorre a pie, con caballerizas y amplios jardines y parques que la rodean. Todas características que ubican a sus moradores en la alta burguesía. Pero los acontecimientos son similares a lo sucedido en Quedlinburg: así como Adrien fue en un principio recibido con reticencia por los padres de Frantz, Anna sólo es aceptada por la madre de Adrien para que se quede en la casa, ante la insistencia de su hijo. El amor que ambos parecen sentir le cuesta abrirse camino: por un lado la madre, que teme por la fragilidad emocional y vulnerabilidad de Adrien (el cuadro de El suicida de Manet está en su habitación, como una premonición); por el otro, una antigua novia, que perdió a su hermano en el frente (con un nombre bastante similar al de Frantz: Francoise) espera ser desposada por él.

Como en la casa familiar alemana, la música es un elemento de catarsis y de consuelo: la novia canta, Anna toca el piano y Adrien, que ya no volverá a trabajar en la Opera, toca el violín. Aquí también el arte une a los jóvenes. Pero las tensiones siguen presentes, traen los malos recuerdos y Anna que teme que Adrien pueda suicidarse alejado de su ámbito familiar, decide alejarse. Hay demasiados obstáculos y culpas y cada uno deberá seguir su camino. Mientras Adrien queda confinado al espacio privado, Anna encuentra las fuerzas para abrirse paso al público, sin depender de un orden patriarcal que organice su vida.

\section{El Museo del Louvre, un espacio integrador}

En el film, el Louvre actúa como el lugar donde transcurre gran parte de la relación de los tres protagonistas pero también es un símbolo de los sentimientos oscuros que posee cada uno de ellos y las amarguras de los ciudadanos que fueron parte activa o pasiva en la guerra. El cuadro de Manet antes mencionado (El suicidio, 1881) atraviesa todo el film mostrándose como la cara de desaliento y pesimismo que sobrevuela los ánimos de la 
posguerra. Desde un principio cuando Adrien se reúne con Anna y los padres de Frantz se refiere al museo y a ese cuadro en particular, que tanto -en palabras de Adrien- "tanto le gustaba a su amigo" Una imagen que nos acompaña hasta el cierre del film, cuando Anna deja atrás su pasado.

Este cuadro es extraño dentro de la producción de Manet, si bien el estilo acompaña al impresionismo y todas sus características, no así la temática abordada. Dentro del movimiento impresionista el tema por excelencia que utilizaban estos artistas para sus cuadros eran los paisajes al natural. Lo que buscaban era recrear esas luces y sombras del sol y sus distintos momentos, utilizando la pincelada y el juego de pigmentos como base para esto. Otro de los temas heredados de los siglos anteriores era el retrato, pero de personas vivas, en general posando con alegría, autoridad o grandeza. No resultaba común en Manet ni en su círculo de artistas presentar retratos dramáticos ni sangrientos. Con respecto al estilo, esta pintura carece de detalles, siguiendo con las pinceladas típicas del impresionismo, pero si tiene un realismo inquietante, sobre todo en ese charco de sangre a los pies del suicida. La escena -inventada por la imaginación de Adrien- en que ambos amigos visitan el museo y se muestran felices y vitales actúa como un punto central en la reconstrucción de una historia que nunca existió; y como metáfora de una amistad entre naciones que hubiera enriquecido y nutrido a sus habitantes. Ese encuentro ficticio aleja a Adrien del verdadero dolor que siente y lo separa del odio irracional entre humanos que fue el leiv motiv de la guerra. El suicidio como tema cruza toda la narración del film y tiene su punto más álgido en la mitad de la película cuando Anna intenta suicidarse, confundida en este proceso que la lleva a la libertad y a un nuevo estado de conciencia.

En la última escena, vemos a Anna frente al cuadro de Manet y un joven -muy parecido a Adrien- le pregunta si le gusta esa imagen. Allí, la obra pictórica actúa como aglutinante de todas las historias del film: por un lado, el suicidio como forma de escape de una realidad dura individual y colectiva (matarse para dar por finalizada una realidad no deseada, y también la guerra como el suicidio de una sociedad) Pero, por otro lado, una imagen emparentada a la vida. La apreciación de Anna acerca del cuadro y el suicidio que en él se ve, resulta muy diferente en el principio y el final del film. En un comienzo la vemos angustiada, más cerca de la muerte que de la vida (yendo y viniendo del cementerio), esta sensación llega al climax en mitad de la película cuando Anna intenta suicidarse. Pero todo cambia en la escena final cuando sentada frente a ese mismo cuadro, reconoce la vida en el muerto, diciendo que ese suicidio le da fuerza para vivir.

Otro punto interesante para reflexionar respecto a este espacio y sus obras es el diálogo que se entablan en las paredes del Louvre, en especial entre El suicidio y Almuerzo en la hierba (1863) obra central de Manet que se encuentra ubicada en la parte superior de la pared, junto al anterior cuadro mencionado. Esta interacción entre la vitalidad y felicidad de ese almuerzo burgués donde hombres y mujeres disfrutan de un día de sol al desnudo, y la contracara de ese hombre encerrado en un cuarto muy pequeño, inerte en la cama después de decidir quitarse la vida resulta una elección interesante para reflexionar y analizar. En este cruce de realidades (y de estilos de pintura) podemos pensar en un antes y un después de la guerra, distintos modos de entender al ser humano, sus actividades y sentimientos. Dos modos de ver el mundo y su historia. 


\section{Conclusión}

Frantz rescata la memoria histórica sobre las terribles consecuencias de la Primera Guerra Mundial, constituyéndose en testimonio simbólico frente al olvido y destaca el rol de la mujer frente a esos acontecimientos. Anna se convierte en protagonista de la película y es desde su punto de vista que observamos el conflicto. El texto fílmico la acompaña en su derrotero y búsqueda de la vida ante la muerte. Así, el comienzo la ubica en el cementerio, triste ante la muerte de su amado, frente a un mundo desolado por la muerte de tantos jóvenes y termina con ella alejándose del cuadro de Manet, y del fantasma del suicidio, para vivir su futuro en plenitud.

En su devenir hay un profundo interés no sólo en retratar el espíritu de la primera pos guerra, sino en dejar bien en claro, el rol femenino y cómo este va mutando en la sociedad. Según de Beauvoir (1987) históricamente la mujer tiene como principal destino el matrimonio, aunque con la incipiente emancipación económica en el contexto social en que transcurre el film, éste se fue convirtiendo en una "unión libremente consentida entre dos individualidades" (p.163) De ese modo -y poco a poco- la mujer va ocupando nuevos espacios sociales. Esta transformación va acompañando al relato en la medida en que Anna va ganando personalidad, presenta una postura activa frente a la vida y busca emerger a la luz de su propia trascendencia. Decide ir a buscar su libertad y su propio destino, soltando las cadenas invisibles que la unen al cementerio y al duelo. Se trata de una actitud que refleja los cambios de la mujer, quien lentamente fue transformando su rol social, dejando a la vista nuevos paradigmas.

Frantz responde así, a la pregunta que Woolf plantea en sus reflexiones -y que aparece en la introducción de este artículo-: Anna no queda confinada al seno familiar sino que supera los obstáculos. Frente a desencuentros amorosos y situaciones adversas, ella se muestra como alguien que logra su crecimiento, que alcanza a evolucionar utilizando al arte y la cultura como sus herramientas.

Los filmes son significativos en tanto interesan a la relación entre la realidad social y su representación cinematográfica. Las imágenes del pasado en Frantz iluminan y enriquecen el presente, en el que la mujer sigue luchando por sus plenos derechos, advirtiendo al conmocionado mundo actual sobre las consecuencias del flagelo de la guerra.

\section{Notas}

1. Sobre La Primera Guerra Mundial ver: Aldcroft, D. H:, De Versalles a Wall Street, 19191929, Barcelona, Ediciones Folio, Tomo I, 1997: Ambrosius, G.y Hubbard, W. H., Historia social y económica de Europa en el siglo XX, Madrid, Alianza Editorial, 1992; Barbero, M. I., Berenblum, R., García Molina, F.R. y Saborido, J.R.E. Historia Económica y Social General, Buenos Aires, Ediciones Macchi, 2001; Hardach, G., La Primera Guerra Mundial, 19141918, Barcelona, Ediciones Folio, 1997; Hobsbawn, E., Historia del Siglo XX, Barcelona, Crítica, 1995; Parker, R.A.C., El siglo XX, Europa, 1918-1945, México, Siglo XXI, 1991; Saborido, J., El fin de la Primera Guerra Mundial, Buenos Aires, Editorial Biblos, 1993 
2. Y en 1914 comenzó la era de las catástrofes (Hobsbawm, 1995) en la que la humanidad debió sufrir la muerte y destrucción de dos guerras mundiales y en el interregno, una crisis económica de magnitud y profundidad inéditas.

3. Sobre la relación entre cine e historia ver: Marzorati, Z, Pombo, M (Comps.) (2019) "Prefacio" en Cine e historia. Representaciones fílmicas en un mundo globalizado. Cuadernos del Centro de Estudios de Diseño y Comunicación No77 ISSN: 1668-0227 Año XI, Buenos Aires, Argentina

4. Entre los principales filmes de Ozon figuran: La piscina, Ocho mujeres, Bajo la arena, En la casa, Joven y bella y El amante doble.

5. Ernst Lubitsch (1892, Berlín-1947, EUA). Realizador que se destacó por una comedia fina y una excelente puesta en escena como en El desfile del amor, La viuda alegre, Ninotchka y Ser o no ser, entre otras. Su cine pone en cuestión la separación de funciones entre ambos sexos: mientras que a los hombres siempre les correspondía un papel activo y a las mujeres, uno pasivo, en sus filmes las mujeres son tan activas como los hombres, muchas veces con más resonancia en sus acciones que ellos (García Brusco, 1988, p.17).

6. Pascal Martí obtuvo el premio César a la mejor fotografía del cine francés de 2016

7. Ozon (2016) La higuera.net (https://www.lahiguera.net/cinemania/pelicula/7720/comentario.php)

\section{Lista de Referencias Bibliográficas}

Briggs, A., Clavin, P. (1997). Historia Contemporánea de Europa. 1789-1989, Barcelona: Crítica

García Brusco, Carlos (1988). Ernst Lubitsch. Madrid: Ediciones JC. Colección Directores de Cine. Número 31

de Beauvoir, Simone (1987) El segundo sexo. Los hechos y los mitos. Buenos Aires: Editorial Siglo Veinte.

Duby, Georges (1989). Prefacio a la Historia de la vida privada. En P. Ariés y G. Duby (Comp.) Historia de la vida privada. Imperio romano y antigüedad tardía. Madrid: Taurus, tomo 1, pp.9-11

Fusi Aizpurúa, J.P. (1991) "La crisis de la conciencia europea” (cap. 12) en Cabrera, M., Juliá,S., y Aceña, P.M. (comps.), Euroa en crisis. Madrid: Editorial Pablo Iglesias

Kershaw, Ian (1999). Hitler. Barcelona: Ediciones Península

Price, Roger (1996). Historia de Francia. Gran Bretaña: Cambridge University Press

Woolf, V. (2008) Una habitación propia. Barcelona: Editorial Seix Barral

Abstract: The actual paper intends to analyze the film Frantz pointing the woman's changes along History.The story in both, a German and French context at the end of First World War, shows the war consequences due to young men's death; familiar tragedies and desolation, destroying the reliability that Europeans had had in their own civilization until then. With an antibelicist discourse, the filmical text reminds that time of desolation and unreliability through three central characters: Frantz, a German dead in trenches, Anna, 
his girl-friend and Adrien, a French who introduces himself as Frantz's friend before war. As History can't be unfastened from discourses and images that represent it, the aim in our paper is to board memory construction (and forgetfulness risks) about the consequences of The Great World War, at the same time it inquieries about feminine perspective in this context. De Beauvoir thinks that it's posible to infer that characteristics inherent to women don't come from nature but as a social complex process. Women take characteristics considered as feminine through a procedure that makes them as the opposite face of the masculine aspect. In the film we can clearly analyze these roles and how in the lapse of the story these borders are being out of perspective to give place to new paradigms.

Ozon centralizes it in Anna, feminine figure, who from a simple spectator that waits and suffers her beloved's lost, turns into in an active woman along the story. It's through her view that the director reflects about the absurdity of war, the forgiveness and reconciliation, the art as escape from horror, and in particular the search of woman's freedom in a patriarcal society.

Key words: The Great War - memory - forgetfulness - gender - images

Resumo: O presente artigo propõe analizar o filme Frantz focalizando nas mudanças da mulher ao longo da história. O relato adaptado na Alemanha e na França no final da Primeira Guerra Mundial, mostra as consequências da guerra dadas pelas mortes de homens jovens, tragédias familiares y desolação, na qual destruiu a confiança que os européus tinham ate então na sua civilização. Com um discurso antibelicista o texto do filme relembra esta etapa de desilusão e falta de esperança através dos seus três personagens centrais: Frantz, alemão morto nas trincheiras; Anna, a sua namorada e Adrien, francês que se apresenta na Alemanha como un amigo de Frantz de antes da guerra.

Como a história não pode se separar dos discursos nem das imagens que a representam, o objetivo do nosso trabalho é abordar a construção da memória (e dos riscos do esquecimento) sobre as conseqüências da Grande Guerra, ao mesmo tempo indaga sobre o olhar feminino neste texto. Segundo de Beauvoir (1987) é possível inferir que as características consideradas próprias das mulheres não são naturais, senão como um complexo processo social. As mulheres adquirem características consideradas como femininas mediante um procedimento que as determina como a contra cara do masculino. No filme, podemos analisar claramente cada papel e como no transcurso da história estes limites vão aparecendo para dar lugar a novos paradigmas.

Ozon centra o seu olhar na figura feminina, Anna, quem de simples espectadora espera e sofre a perda do seu amado, se transforma ao longo do relato em uma mulher ativa. É através da sua observação que o diretor reflete sobre o absurdo da guerra, do perdão e a reconciliação, a arte como uma fuga do horror e em particular, da busca da liberdade da mulher numa sociedade patriarcal.

Palavras chave: Grande Guerra - memória - esquecimento - gênero - imágens

[Las traducciones de los abstracts fueron supervisadas por el autor de cada artículo] 